\title{
Chloroquine Stimulates Nitric Oxide Synthesis in Murine, Porcine, and Human Endothelial Cells
}

\author{
Dario Ghigo, Elisabetta Aldieri, Roberta Todde, Costanzo Costamagna, Giovanni Garbarino, ${ }^{\star}$ Gianpiero Pescarmona, \\ and Amalia Bosia \\ Department of Genetics, Biology, and Biochemistry, and *Department of Internal Medicine, University of Torino, 10126 Torino, Italy
}

\begin{abstract}
Nitric oxide (NO) is a free radical involved in the regulation of many cell functions and in the expression of several diseases. We have found that the antimalarial and antiinflammatory drug, chloroquine, is able to stimulate NO synthase (NOS) activity in murine, porcine, and human endothelial cells in vitro: the increase of enzyme activity is dependent on a de novo synthesis of some regulatory protein, as it is inhibited by cycloheximide but is not accompanied by an increased expression of inducible or constitutive NOS isoforms. Increased NO synthesis is, at least partly, responsible for chloroquine-induced inhibition of cell proliferation: indeed, NOS inhibitors revert the drug-evoked blockage of mitogenesis and ornithine decarboxylase activity in murine and porcine endothelial cells. The NOS-activating effect of chloroquine is dependent on its weak base properties, as it is exerted also by ammonium chloride, another lysosomotropic agent. Both compounds activate NOS by limiting the availability of iron: their stimulating effects on NO synthesis and inhibiting action on cell proliferation are reverted by iron supplementation with ferric nitrilotriacetate, and are mimicked by incubation with desferrioxamine. Our results suggest that NO synthesis can be stimulated in endothelial cells by chloroquine via an impairment of iron metabolism. (J. Clin. Invest. 1998. 102:595-605.) Key words: ammonium chloride $\bullet$ desferrioxamine $\cdot$ ferric nitrilotriacetate $\bullet$ lysosomotropic agents • ornithine decarboxylase
\end{abstract}

\section{Introduction}

Nitric oxide $(\mathrm{NO})^{1}$ is a short-lived messenger molecule produced in many mammalian cell types (1) and involved in a wide spectrum of activities, such as smooth muscle relaxation,

Address correspondence to Dario Ghigo, Dipartimento di Genetica, Biologia e Biochimica, Sezione di Biochimica, Via Santena 5/bis, 10126 Torino, Italy. Phone: 39-11-6706685; FAX: 39-11-6635663; E-mail: ghigo@molinette.unito.it 1998

Received for publication 27 June 1997 and in revised form 21 May

1. Abbreviations used in this paper: CFDA, carboxyfluorescein diacetate; ecNOS, endothelial constitutive nitric oxide synthase; FeNTA, ferric nitrilotriacetate; iNOS, inducible nitric oxide synthase; NO, nitric oxide; NOS, nitric oxide synthase; ODC, ornithine decarboxylase; PAEC, porcine aortic endothelial cells.

J. Clin. Invest.

(C) The American Society for Clinical Investigation, Inc. 0021-9738/98/08/0595/11 \$2.00

Volume 102, Number 3, August 1998, 595-605

http://www.jci.org inhibition of platelet activation, neurotransmission, and cytotoxicity (2). A class of NADPH-dependent NO synthases (NOS), competitively inhibited by L-arginine analogues, favors the conversion of L-arginine to L-citrulline and $\mathrm{NO}$ with a 1:1 stoichiometry $(3,4)$. In oxygenated living systems, NO is rapidly converted into nitrite and nitrate. At least three different isoenzymes have been characterized (5): two of them are constitutive (endothelial and neuronal cNOS), and one is an inducible iNOS detected in macrophages.

NO plays an important role in aspecific immunity, and is effective against various microbes and tumor cells (6). As an example, NO has been involved in the host control of progression of malaria infection. It has been suggested that the parasite induces host cells (leucocytes, endothelium, hepatocytes, etc.) to produce NO by eliciting an enhanced synthesis of cytokines (TNF, IL-1, IFN- $\gamma$, IL-6, etc.) (7-9) or by releasing a NOS-activating soluble factor (10); NO reduces the growth and invasiveness of asexual blood stages and exoerythrocytic stages of parasites (11-16), and killing of malaria parasites by the mouse immune system correlates with increased levels of reactive nitrogen intermediates in plasma $(17,18)$.

Chloroquine is an aminoquinolinic drug used in treatment of several pathologic conditions, such as malaria infection and autoimmune diseases (rheumatoid arthritis and lupus erythematosus). Indeed, it inhibits parasite growth (19) and blocks cytokines production and proliferation in monocytes, macrophages, and lymphocytes $(20,21)$. The mechanism of action and the molecular targets of chloroquine are not completely known: its antimalarial properties have been attributed, at least partly, to the ability to inhibit a heme polymerase in Plasmodium falciparum trophozoites (22), but it is poorly understood how it acts as an immunosuppressive drug. Owing to its weak base properties, chloroquine may accumulate in acid intracellular compartments (23), causing a $\mathrm{pH}$ increase and thus interfering with endocytosis, exocytosis, phagocytosis (21), and other related phenomena, such as antigen presentation and iron metabolism (20).

Our study has been aimed to demonstrate that: $a$ ) chloroquine stimulates NO synthesis in endothelial cells; $b$ ) chloroquine-evoked NO synthesis is, at least partly, responsible for the inhibition of cell proliferation induced by the drug; $c$ ) these effects are mediated by the ability of the drug to affect iron metabolism via a lysosomotropic mechanism.

\section{Methods}

Reagents. FCS was supplied by GIBCO BRL (Paisley, Scotland); plastic for cell culture was from Falcon (Becton Dickinson, Bedford, MA); the cationic exchange resin Dowex AG50WX-8, N-(1-naphthylethylenediamine) dihydrochloride, and sulfanilamide were from Aldrich Italia (Milan, Italy); L- $\left[2,3,4,5-{ }^{3} \mathrm{H}\right]$ arginine monohydrochloride $(62 \mathrm{Ci} / \mathrm{mmol})$ and $\mathrm{DL}-\left[1-{ }^{14} \mathrm{C}\right]$ ornithine $(58 \mathrm{mCi} / \mathrm{mmol})$ were obtained from Amersham International (Bucks, UK); 6-carboxyfluorescein diacetate (CFDA) was from Calbiochem-Behring (San Diego, 
CA). Other reagents were purchased from Sigma Chemical Co. (St. Louis, MO). Mouse monoclonal antibodies anti-human endothelial cNOS (ecNOS) and anti-murine macrophage iNOS, directed against 20.4-22.3-kD protein fragments (ecNOS: amino acids 1030-1209; iNOS: amino acids 961-1144), were from Transduction Laboratories (Lexington, KY). Electrophoresis reagents were obtained from BioRad Laboratories (Hercules, CA). The protein content of cell monolayers and cell lysates was assessed with the BCA kit from Pierce (Rockford, IL).

Composition of Hepes-Na/EDTA buffer $(\mathrm{mM})$ : Hepes $\left(\mathrm{Na}^{+}\right.$salt) 20, EDTA 2, pH 6. Composition of Hepes/EDTA/DTT buffer (mM): Hepes 20, EDTA 0.5, DTT 1, pH 7.2. Composition of $\mathrm{Na}^{+}$solution (mM): $145 \mathrm{NaCl}, 5 \mathrm{KCl}, 1 \mathrm{MgSO}_{4}, 10$ Hepes, 10 glucose, $1 \mathrm{CaCl}_{2}, \mathrm{pH}$ 7.4. Composition of $\mathrm{K}^{+}$solution (mM): $15 \mathrm{NaCl}, 120 \mathrm{KCl}, 1 \mathrm{MgSO}_{4}$, 20 Hepes, 10 glucose; $\mathrm{pH}$ was adjusted at different values with Tris $\left(6.6-7.8\right.$ at $\left.37^{\circ} \mathrm{C}\right)$. Hepes-Ca buffer $(\mathrm{mM}): \mathrm{NaCl} 145, \mathrm{KCl} 5, \mathrm{MgSO}_{4} 1$, Hepes-Na 10, glucose 10, $\mathrm{CaCl}_{2}$ 1, $\mathrm{pH}$ 7.4.

Cell cultures. sEnd.1 cell line, murine endothelial cells transformed by middle $\mathrm{T}$ antigen of polyoma virus (24), were grown in DME supplemented with 10\% FCS. ECV-304 (immortalized human umbilical vein endothelial cells) cell line was a kind gift of Ruggero Pardi (Dibit, San Raffaele Hospital, Milan, Italy), and was cultured as sEnd.1 cells. Porcine aortic endothelial cells (PAEC) were isolated as previously described (25) and cultured in Ham's F-12 supplemented with $10 \%$ FCS. In each experimental condition, cell viability was checked by trypan blue exclusion, and never decreased under $95 \%$.

Measurement of NOS activity in cell lysates. Cells grown at confluence on 35-mm diameter Petri dishes, after incubation in the experimental conditions described in Results, were detached by trypsin/ EDTA $(0.05 / 0.02 \% \mathrm{vol} / \mathrm{vol})$; the cells from each dish were washed with PBS, and then resuspended in $0.3 \mathrm{ml}$ of reaction buffer (mM: Hepes 20, EDTA 0.5, DTT 1, pH 7.2) and sonicated on ice with two $10 \mathrm{~s}$ bursts. In each test tube, the following reagents were added to $100 \mathrm{ml}$ lysate at the final concentrations: $2 \mathrm{mM} \mathrm{NADPH}, 2.5 \mu \mathrm{Ci}$ $\mathrm{L}-\left[{ }^{3} \mathrm{H}\right]$ arginine $(=0.4 \mu \mathrm{M})(26,27)$. In these conditions, due to the presence of $0.5 \mathrm{mM}$ EDTA, only the $\mathrm{Ca}^{++}$-independent NOS activity was detectable; by adding $1.5 \mathrm{mM} \mathrm{CaCl}$ (final concentration) to the lysate, it was possible to measure the $\mathrm{Ca}^{++}$-dependent NOS activity. When indicated, NOS inhibitors were added to the other reagents. After a 15 -min incubation at $37^{\circ} \mathrm{C}$, the reaction was stopped by adding $2 \mathrm{ml}$ Hepes-Na/EDTA buffer; the whole reaction mixture was applied to 2-ml columns of Dowex AG50WX-8 ( $\mathrm{Na}^{+}$form) and eluted with $4 \mathrm{ml}$ of water. The radioactivity corresponding to $\left[{ }^{3} \mathrm{H}\right]$ citrulline content in $6.1 \mathrm{ml}$ eluate was measured by liquid scintillation counting. Citrulline synthesis was expressed as pmol citrulline $/ \mathrm{min} / \mathrm{mg}$ cell protein.

Measurement of nitrite. Confluent cell cultures in 35-mm diameter Petri dishes were incubated in fresh medium for 6-24 h in the experimental conditions indicated in Results. Then nitrite production was measured by adding $0.15 \mathrm{ml}$ of cell culture medium to $0.15 \mathrm{ml}$ of Griess reagent (28) in a 96-well plate, and, after a 10-min incubation at $37^{\circ} \mathrm{C}$ in the dark, absorbance was measured at $540 \mathrm{~nm}$ in a Packard EL340 microplate reader. A blank was prepared for each experimental condition in the absence of cells, and its absorbance was subtracted from that obtained in the presence of cells. Nitrite concentration was expressed as nmol of nitrite produced in $24 \mathrm{~h} / \mathrm{mg}$ cell protein.

Western blots. Cells were directly solubilized in boiling Laemmli buffer (containing $2 \mathrm{mM}$ PMSF and $0.5 \mathrm{mM}$ EDTA), and proteins, separated by SDS-PAGE (7\%), were transferred to nitrocellulose sheets and probed with a monoclonal antibody (diluted 1:500 in PBS-BSA $1 \%$ ) anti-iNOS or anti-ecNOS; after $1 \mathrm{~h}$ of incubation, the membrane was washed with PBS-Tween $0.1 \%$ and subjected to a peroxidase-conjugated antibody (diluted 1:1,000 in PBS-Tween with Blocker Non-Fat Dry Milk 5\%, Bio-Rad) anti-mouse IgG (sheep; Amersham). The nitrocellulose was washed again with PBS-Tween and proteins were detected by enhanced chemiluminescence (Amersham International).

$m R N A$ analysis of ecNOS. Total RNA was obtained by the guanidine isothiocyanate/cesium chloride method (29). $25 \mu \mathrm{g}$ of total RNA were electrophoresed on a $1 \%$ agarose gel containing $6.3 \%$ formaldehyde in Mops buffer and blotted on a Nylon Duralon-UV membrane (Stratagene, La Jolla, CA) by the traditional capillary system in $10 \times$ SSC (30). Prehybridization and hybridization steps were performed overnight in $50 \%$ deionized formamide, $10 \%$ dextran sulfate, $1 \mathrm{M} \mathrm{NaCl}$, with $100 \mu \mathrm{g} / \mathrm{ml}$ denaturated salmon sperm DNA at $42^{\circ} \mathrm{C}$. The cDNA for endothelial cNOS (a gift from T. Michel, Brigham and Women's Hospital, Boston, MA) was labeled with $\alpha-\left[{ }^{32} \mathrm{P}\right] \mathrm{dCTP}(3,000 \mathrm{Ci} / \mathrm{mmol}$, Amersham International $)$ at $2.2 \times 10^{8}$ $\mathrm{cpm} / \mu \mathrm{g}$ sp act by the random primer labeling kit (Amersham International), according to the manufacturer's instructions. Posthybridization washes were performed at high stringency (twice in $2 \times$ SSC plus $0.1 \%$ SDS for $30 \mathrm{~min}$ at room temperature, twice in $0.2 \times$ SSC plus $0.1 \%$ SDS for $30 \mathrm{~min}$ at room temperature, and twice in $0.1 \times \mathrm{SSC}$ plus $0.1 \%$ SDS for $30 \mathrm{~min}$ at $55^{\circ} \mathrm{C}$ ), and the membrane was exposed on autoradiography with Hyperfilm-MP (Amersham International) and intensifying screens at $-80^{\circ} \mathrm{C}$.

Measurement of free cytosolic $\mathrm{Ca}^{++}\left(\left[\mathrm{Ca}^{++}\right] \mathrm{i}\right)$. Cells were seeded on sterile glass coverslips (12-mm diameter) and let to grow to confluence, and then incubated for $24 \mathrm{~h}$ in the presence or absence of $20 \mu \mathrm{M}$ chloroquine. The integrity of the monolayer was assessed by light microscopy examination. $\left[\mathrm{Ca}^{++}\right]$i transients were measured by using the calcium-sensitive fluorescent probe Fluo3 acetoxy methylester (Fluo3-AM) (31). A non-ionic surfactant, Pluronic F-127, was used to aid solubilization of the Fluo3-AM into aqueous medium. $1 \mu \mathrm{l}$ of a $25 \%$ (w/w) stock solution of Pluronic F-127 in dry DMSO was mixed with every $10 \mathrm{nmol}$ of Fluo3-AM before thoroughly dispersing the mixture into aqueous solution (31). Coverslips were incubated for 30 min in the presence of $10 \mu \mathrm{M}$ Fluo3-AM in Hepes-Ca buffer at $37^{\circ} \mathrm{C}$ and $5 \% \mathrm{CO}_{2}$ atmosphere. After loading, coverslips were washed with Hepes-Ca buffer. Fluorescence of intracellular Fluo3 was measured in a Perkin-Elmer LS-5 spectrofluorometer. The standard monochromator settings were 490-nm excitation (5-nm slit width) and 530-nm emission (10-nm slit width). For the test, the coverslip was firmly positioned in a quartz cuvette $(1 \mathrm{~cm})$ containing $1 \mathrm{ml}$ of Hepes-Ca buffer; the cuvette holder was thermostatted at $37^{\circ} \mathrm{C}$. Fluorescence spectral analysis of adherent cells after loading revealed a peak at $520-530 \mathrm{~nm}$, demonstrating intracellular accumulation of Fluo3. For calibration, the fluorescence of $\mathrm{Ca}^{++}$-saturated dye $\left(\mathrm{F}_{\max }\right)$ was taken as the maximal emission from cells treated with $10 \mu \mathrm{M}$ ionomycin in $\mathrm{Ca}^{++}$-containing medium. $2 \mathrm{mM}$ EGTA, which enters the cells via the ionophore and quenches Fluo3 fluorescence completely, was then added. The resulting fluorescence $\left(\mathrm{F}_{\min }\right)$ was essentially equal to the background signal obtained before Fluo3 loading. Calculation of $\left[\mathrm{Ca}^{++}\right] \mathrm{i}$ levels was performed as previously described (31).

Measurement of cytosolic aconitase activity. Cells grown at confluence on 100-mm diameter Petri dishes, after incubation in the experimental conditions described in Results, were detached by trypsin/ EDTA $(0.05 / 0.02 \% \mathrm{vol} / \mathrm{vol})$; the cells from each dish were washed with PBS, and then resuspended in lysis buffer containing $0.1 \%$ Triton $\mathrm{X}-100$ and $50 \mathrm{mM}$ Hepes ( $\mathrm{pH} 7.4)$; the protease inhibitors PMSF $(10 \mu \mathrm{M})$, aprotinin $(10 \mu \mathrm{M})$, and $\epsilon$-aminocaproic acid $(20 \mu \mathrm{M})$ were then added. Cytosolic aconitase was separated from the mitochondrial aconitase by centrifugation at $13,000 \mathrm{rpm}$ for $10 \mathrm{~min}$ at $14^{\circ} \mathrm{C}$; therefore, the residual mitochondrial aconitase in the supernatant was inhibited by incubation for $30 \mathrm{~min}$ at $0^{\circ} \mathrm{C}$ with $10 \mathrm{mM}$ ferrozine. Most assays of aconitase were performed by adding $50 \mu \mathrm{l}$ of the soluble fraction of the cell lysate into a quartz cuvette containing $1 \mathrm{ml}$ of

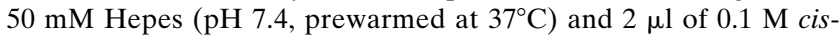
aconitate. The mixture was placed in a spectrophotometer (PerkinElmer Lambda 3) cuvette holder thermostatted at $37^{\circ} \mathrm{C}$. Aconitase activity was assayed by directly monitoring aconitate absorbance decrease at $240 \mathrm{~nm}$ (32). Blank incubations lacking aconitate were subtracted. Cytosolic aconitase activity was calculated as nmol/min/mg cell protein.

Measurement of heme by luminescence. Heme-enhanced luminescence was measured taking advantage of the heme-associated per- 
oxidase activity that catalyses electron transfer from t-buthylhydroperoxide to luminol (5-amino-2,3-dihydro-1,4-phtalazinedione). Cells grown at confluence on 100-mm diameter Petri dishes, after incubation in the experimental conditions described in Results, were detached by trypsin/EDTA $(0.05 / 0.02 \% \mathrm{vol} / \mathrm{vol})$; the cells from each dish were washed with PBS, and then resuspended in lysis buffer containing $0.1 \%$ Triton $\mathrm{X}-100$ and $50 \mathrm{mM}$ Hepes (pH 7.4). $0.1 \mathrm{ml}$ luminol/ $\mathrm{NaOH}$ solution (luminol $1 \mu \mathrm{g} / \mathrm{ml}$, dissolved in $0.1 \mathrm{M} \mathrm{NaOH} / 3 \mathrm{mM}$ EDTA) and $0.1 \mathrm{ml}$ t-buthylhydroperoxide $/ \mathrm{NaOH}$ solution $(7.26 \mathrm{mM}$ t-buthylhydroperoxide dissolved in $0.1 \mathrm{M} \mathrm{NaOH} / 3 \mathrm{mM}$ EDTA) were injected simultaneously into a cuvette with $5 \mu$ l of cell lysate. Luminescence output, expressed as counts per second (cps), was measured during $2 \mathrm{~s}$ at room temperature, using a lumimeter Lumac 2000 with automatic injection, and calculated as pmol heme/mg cell protein (33).

Cytosolic $\mathrm{pH}(\mathrm{pHi})$ determination. Cells were seeded on sterile glass coverslips (12-mm diameter), let to grow to confluence, and then incubated for $24 \mathrm{~h}$ in the presence or absence of $20 \mu \mathrm{M}$ chloroquine. The cell-coated coverslips were washed twice with $\mathrm{Na}^{+}$solution and incubated for $15 \mathrm{~min}$ in a $37^{\circ} \mathrm{C}$ water bath with $30 \mu \mathrm{M}$ 6-CFDA in $\mathrm{Na}^{+}$-solution. 6-CFDA readily enters the cells, where esterases remove the two acetate groups; the resulting non permeant 6-CF is trapped in the cytoplasm. When excited at $490 \mathrm{~nm}$, the intensity of its emission at $520 \mathrm{~nm}$ is a function of $\mathrm{pH}$. After 6-CF loading, the coverslips were washed twice with $\mathrm{Na}^{+}$-solution and put for fluorescence determination in $1 \mathrm{ml}$ of $\mathrm{K}^{+}$-solution at different $\mathrm{pH}$ : calibration of the fluorescence signal and $\mathrm{pHi}$ measurement have been performed as previously described $(34,35)$. To check $\mathrm{pHi}$ variations in cells after short-term chloroquine treatment, we placed control PAEC monolayers in $\mathrm{Na}^{+}$-solution, added $20 \mu \mathrm{M}$ chloroquine, and fluorescence was monitored during the following $20 \mathrm{~min}$ as previously described (35).

Measurement of ornithine decarboxylase (ODC) activity. Cells grown at confluence in 35-mm diameter Petri dishes were detached with trypsin/EDTA, washed with PBS, and resuspended in $300 \mu \mathrm{l}$ of $50 \mathrm{mM}$ Tris- $\mathrm{HCl}, \mathrm{pH}$ 7.4; suspension was sonicated with two $10 \mathrm{~s}$ bursts and incubated in a reaction mixture containing DL- $\left[1-{ }^{14} \mathrm{C}\right]$ ornithine and L-ornithine, as previously described (36). ODC activity was measured as a function of $\mathrm{CO}_{2}$ released during $1 \mathrm{~h}$ of incubation, and expressed as $\mathrm{pmol} \mathrm{CO}_{2} / \mathrm{h} / \mathrm{mg}$ cell proteins.

Determination of cells number by crystal violet staining. Cells were plated at 2,000/well in a 96-well plate and, after $24 \mathrm{~h}$ of incubation at the experimental conditions indicated, checked for cell number with a photometrical method as previously described (37): cells were fixed with glutaraldehyde, and their nuclei were then stained with crystal violet solution; after washing, crystal violet absorbed by the nuclei was extracted, and its absorbance was read at $590 \mathrm{~nm}$ in a Packard EL340 microplate reader.

Statistical analysis. Each experimental point has been performed in duplicate or triplicate per experiment; all data in the text and figures are given as means \pm SEM. Statistical analysis was carried out using the Student's $t$ test for unpaired data.

\section{Results}

NO synthesis is stimulated by chloroquine. sEnd.1 cells exhibited a detectable NOS activity, measured as ability of the cell lysate to convert L- $\left[{ }^{3} \mathrm{H}\right]$ arginine into L- $\left[{ }^{3} \mathrm{H}\right]$ citrulline (Fig. 1). This activity was completely inhibited when assessed in the lysate in the presence of the NOS inhibitors L-canavanine and $\mathrm{N}^{\mathrm{G}}$-nitro-L-arginine methyl ester (Fig. 1). When compared to controls, NOS activity was significantly increased in cells incubated for $24 \mathrm{~h}$ with 5-50 $\mu \mathrm{M}$ chloroquine, reaching a maximal effect at $20 \mu \mathrm{M}$ (Fig. 1); a similar pattern was observed in PAEC (not shown). For this reason, we used $20 \mu \mathrm{M}$ chloroquine in the subsequent experiments. After a 24-h incubation

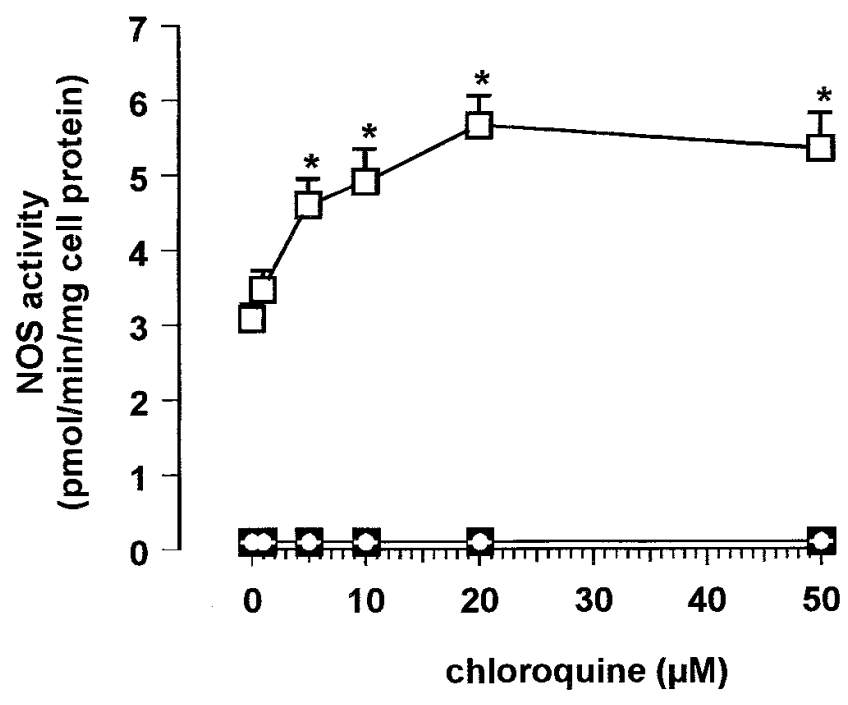

Figure 1. NOS activity in sEnd.1 cells incubated for $24 \mathrm{~h}$ in DME + $10 \%$ FCS with 0-50 $\mu \mathrm{M}$ chloroquine, in the absence (open square) or presence (closed square) of $1 \mathrm{mM}$ L-canavanine or $\mathrm{N}^{\mathrm{G}}$-nitro-L-arginine methyl ester (open circle). After this time, NOS activity was measured in the cell lysates, as described in Methods. Measurements were performed in duplicate, and data are presented as means \pm SEM $(n=8)$. Versus $0 \mu \mathrm{M}$ chloroquine: $* P<0.02$.

of sEnd.1 cells and PAEC in the presence of $20 \mu \mathrm{M}$ chloroquine, nitrite levels in the culture supernatants were significantly higher than in corresponding controls (Fig. 2). Chloroquine-induced nitrite accumulation was dependent on $\mathrm{NO}$ production, as it was inhibited by coincubation of cells with different NOS inhibitors $\left(\mathrm{N}^{\mathrm{G}}\right.$-nitro-L-arginine methyl ester, L-canavanine, aminoguanidine) or with packed human erythrocytes, used as reservoir of the NO scavenger hemoglobin (Fig. 2). In the lysate of the same PAEC used to detect nitrite accumulation, NOS activity was measured both in the presence and absence of $\mathrm{Ca}^{++}$. The $\mathrm{Ca}^{++}$-dependent enzyme activity was significantly increased in chloroquine-treated cells in comparison with controls, whereas the $\mathrm{Ca}^{++}$-independent activity was not modified (Fig. 3). In the subsequent experiments, we then checked always the $\mathrm{Ca}^{++}$-dependent activity.

The chloroquine-evoked synthesis of $N O$ is dependent on a de novo synthesis of proteins, but it does not require an increase of NOS expression. Western blot experiments showed the presence in PAEC and sEnd.1 cells of both the ecNOS and the macrophagic iNOS isoforms, as bands of $\sim 130 \mathrm{kD}$ (Fig. 4 A). Chloroquine $(20 \mu \mathrm{M}, 24 \mathrm{~h})$ did not modify the amount of ecNOS and iNOS, thus ruling out the possibility that the drug induced an increased NOS expression. Northern blot experiments excluded that the increase of $\mathrm{Ca}^{++}$-dependent NOS activity could be due to an augmented expression of ecNOS mRNA transcription (Fig. $4 B$ ). In PAEC and sEnd.1 cells the chloroquine-evoked increase of $\mathrm{NO}$ synthesis was already detectable after a 6-h incubation, when measured as both NOS activity in the lysate and nitrite accumulation in the extracellular medium (Fig. 5). The increase of NOS activity and NO production were dependent on a de novo protein synthesis, as both of them were blocked by coincubation with cycloheximide (Fig. 5). 

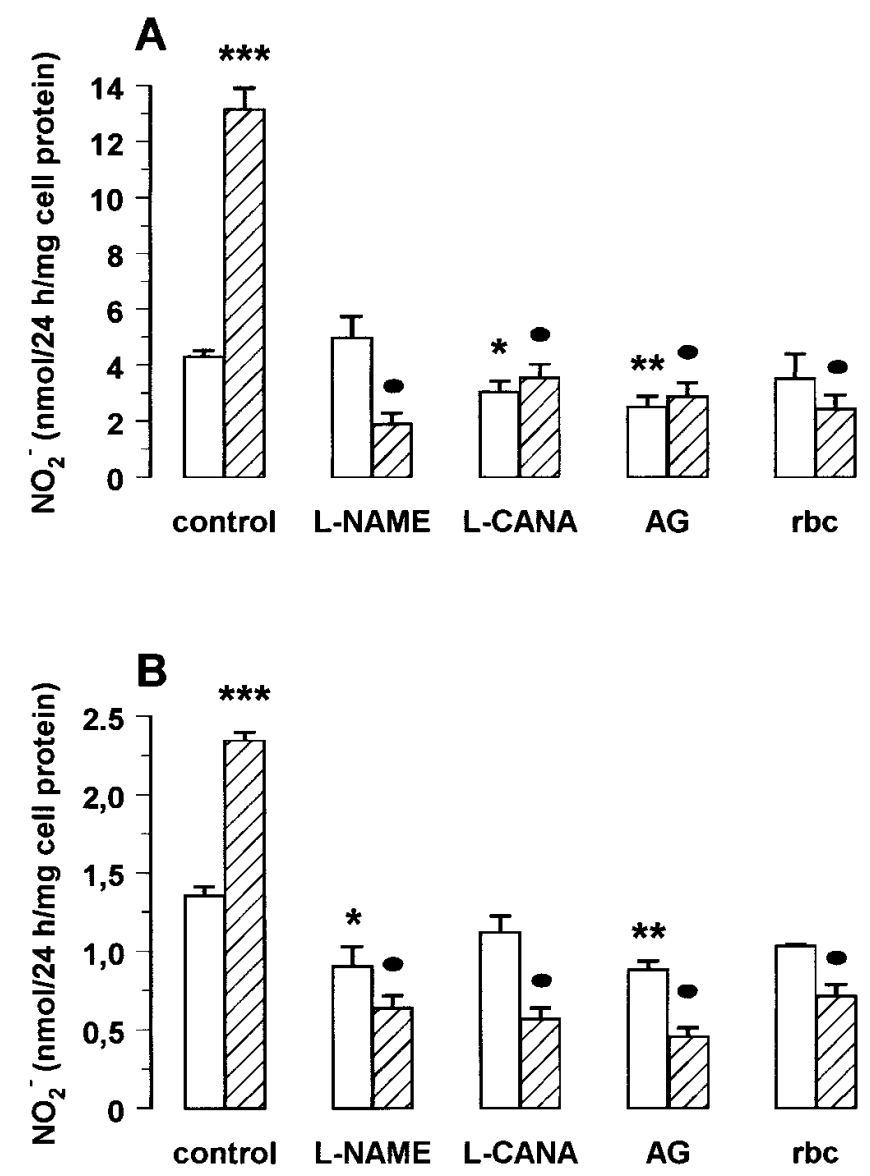

Figure 2. Nitrite levels in extracellular medium of sEnd.1 cells $(A)$ and PAEC $(B)$ incubated for $24 \mathrm{~h}$ in the absence (open bar) or presence (hatched bar) of chloroquine $(20 \mu \mathrm{M})$, and in the absence or presence of $\mathrm{N}^{\mathrm{G}}$-nitro-L-arginine methyl ester $(L-N A M E, 1 \mathrm{mM})$, L-canavanine ( $L$-CANA, $1 \mathrm{mM})$, aminoguanidine $(A G, 1 \mathrm{mM})$, packed human red blood cells $(5 \mu \mathrm{l} / \mathrm{ml}, r b c)$. After this time, extracellular medium was removed and checked for nitrite concentration, as described in Methods. Measurements were performed in duplicate, and data are presented as means \pm SEM (sEnd.1: $n=4$; PAEC: $n=6$ ). Versus control: $* P<0.05, * * P<0.01, * * * P<0.0001$; versus chloroquine: (closed circle) $P<0.0001$.

Chloroquine inhibits cell proliferation in a NO-dependent way. NO at high concentrations may act as a cytotoxic agent. Thus, the chloroquine-induced increase of NO synthesis could be paralleled by an inhibition of cell proliferation. One of the most sensitive indexes of cell proliferation is the activity of ODC, a key enzyme of polyamine synthesis (38). A 24-h chloroquine treatment evoked in sEnd.1 cells a profound decrease of ODC activity (Fig. 6), which was significantly reverted by coincubation with NOS inhibitors $\left(\mathrm{N}^{\mathrm{G}}\right.$-nitro-L-arginine methyl ester, L-canavanine). The determination of cell number by crystal violet staining in PAEC and sEnd. 1 cells confirmed that the inhibitory effect exerted by chloroquine on cell growth was dependent on NO synthesis, as such an effect was significantly reverted by the NOS inhibitors (Fig. 7).

Chloroquine increases NO synthesis owing to its lysosomotropism. Chloroquine can act as a weak base, accumulating in acid cell compartments and increasing $\mathrm{pH}$ rapidly; by this way,
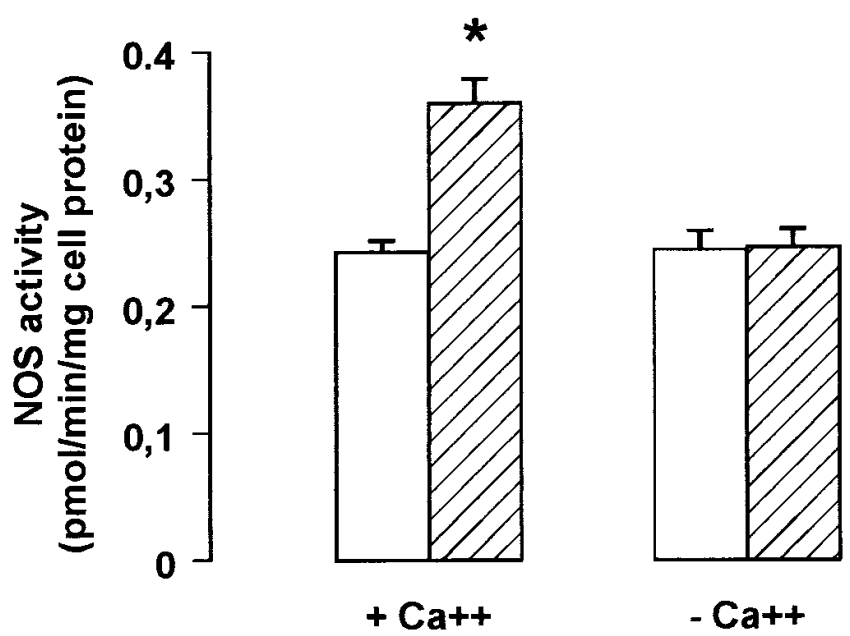

Figure 3. NOS activity in PAEC incubated for $24 \mathrm{~h}$ in the absence (open bar) or presence (hatched bar) of chloroquine $(20 \mu \mathrm{M})$; the activity was measured in the cell lysate in the presence $\left(+\mathrm{Ca}^{++}\right)$or in the absence $\left(-\mathrm{Ca}^{++}\right)$of $0.5 \mathrm{mM} \mathrm{CaCl}_{2}$. Measurements were performed in duplicate, and data are presented as means $\pm \operatorname{SEM}(n=3)$. Versus $0 \mu \mathrm{M}$ chloroquine: $* P<0.0001$.

the drug can interfere with the functions of the acid vesicle system (lysosomes and endosomes) (23). To relate the NOS-activating effect of chloroquine to its weak base behavior, we compared the effect of another lysosomotropic agent, $\mathrm{NH}_{4} \mathrm{Cl}$, on NO synthesis in sEnd.1 cells (Fig. $8 A$ ) and PAEC (Fig. $8 B$ ): ammonium chloride exerted the same activating effect of chloroquine on nitrite accumulation in the extracellular medium (Fig. 8). In parallel, NOS activity in the cell lysate was significantly increased by a 24-h incubation with $20 \mathrm{mM} \mathrm{NH}_{4} \mathrm{Cl}$ both in sEnd. 1 cells $(6.78 \pm 0.38 \mathrm{pmol} / \mathrm{min} / \mathrm{mg}$ cell protein versus $3.39 \pm 0.28 \mathrm{pmol} / \mathrm{min} / \mathrm{mg}$ cell protein in controls, $P<0.001, n=$ $4)$ and in PAEC $(0.479 \pm 0.027 \mathrm{pmol} / \mathrm{min} / \mathrm{mg}$ cell protein versus $0.253 \pm 0.009 \mathrm{pmol} / \mathrm{min} / \mathrm{mg}$ cell protein in controls, $P<0.02$, $n=4)$, whereas cell proliferation was inhibited in the same experimental conditions (Fig. 9).

Chloroquine stimulates $N O$ synthesis by limiting the availability of iron. Chloroquine and $\mathrm{NH}_{4} \mathrm{Cl}$, by increasing lysosomal and endocytic vesicle $\mathrm{pH}$, may interfere with intracellular free iron availability (39). To clarify the possible involvement of this mechanism in our experimental conditions, we added to the cells ferric nitrilotriacetate (FeNTA), an iron chelate compound able to hold iron in a soluble form also at neutral or alkaline $\mathrm{pH}$ (39). After a 24-h incubation, FeNTA reverted the effect of chloroquine and $\mathrm{NH}_{4} \mathrm{Cl}$ on nitrite production (Fig. 8) and cell proliferation (Fig. 9) both in sEnd.1 cells and PAEC, thus suggesting that their action was dependent on the ability to interfere with iron metabolism. The dependence of NO synthesis on iron availability was confirmed by the effect of the iron chelator desferrioxamine; this compound stimulated nitrite synthesis (Fig. 8) and inhibited cell growth (Fig. 9), and FeNTA reverted both effects (Figs. 8-9). As well as chloroquine, in sEnd.1 cells, the effect of desferrioxamine on NOS activity and nitrite production was already detectable after a 6-h incubation, and reverted by cycloheximide and FeNTA (Fig. 10, $A$ and $B$ ). 
A

PAEC

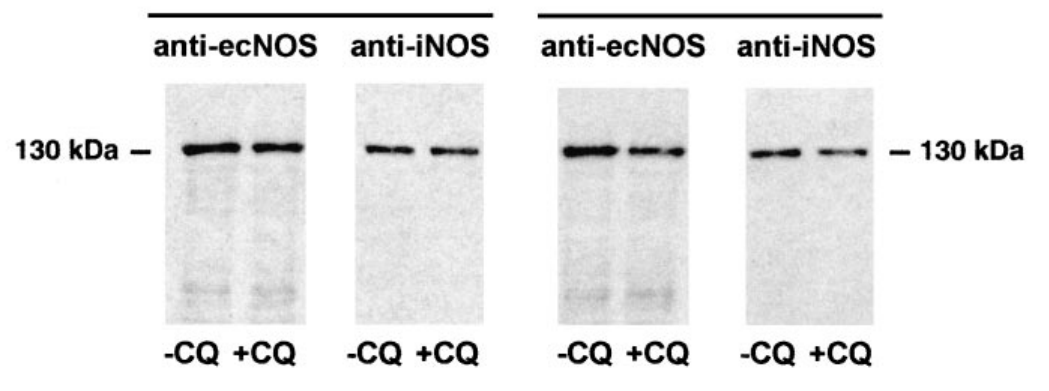

sEnd.1

\section{B}

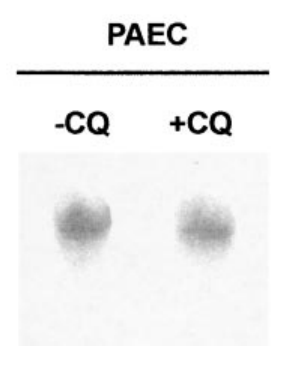

Figure 4. (A) Western blot detection of the endothelial cNOS (ecNOS) and inducible ( $i N O S)$ isoforms, identified as $\sim 130 \mathrm{kDa}$ band, in PAEC and sEnd. 1 cells incubated for $24 \mathrm{~h}$ in the presence $(+C Q)$ or absence $(-C Q)$ of $20 \mu \mathrm{M}$ chloroquine. This experiment is representative of three similar experiments. (B) Expression of the ecNOS mRNA in PAEC and sEnd.1 cells incubated for $24 \mathrm{~h}$ in the presence $(+C Q)$ or absence $(-C Q)$ of $20 \mu \mathrm{M}$ chloroquine. This Northern blot experiment is representative of two similar experiments.
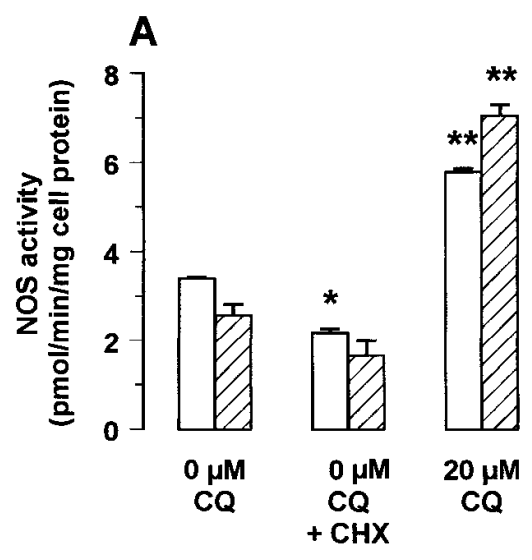

B

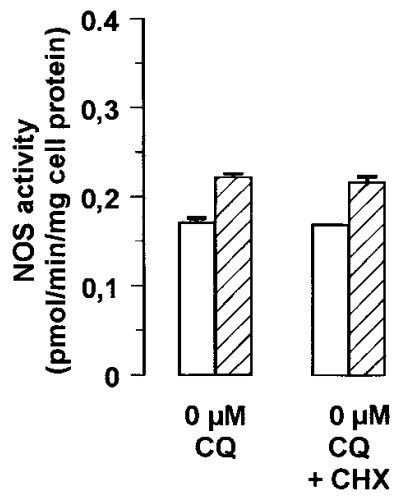

sEnd.1

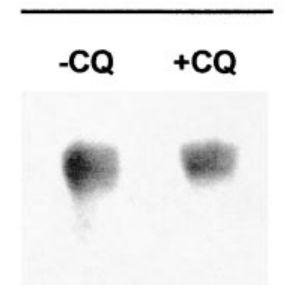

Chloroquine does not influence the level of the iron-containing molecules aconitase and heme. To evaluate the role played by chloroquine in modifying the bioavailability of iron, we measured the activity of cytosolic aconitase (an enzyme containing an iron-sulfur cluster that plays a key role in controlling iron use by the cell) (40) and the level of total heme. The cytosolic aconitase activity in PAEC after incubation with $20 \mu \mathrm{M}$ chloroquine for $24 \mathrm{~h}(14.95 \pm 1.54 \mathrm{nmol} / \mathrm{min} / \mathrm{mg}$ cell protein, $n=5$ ) was not significantly changed in comparison with controls $(11.52 \pm 0.85 \mathrm{nmol} / \mathrm{min} / \mathrm{mg}$ cell protein, $n=5)$. Also the heme content in PAEC was not significantly modified by chloroquine incubation in the same conditions (control: $8.33 \pm 1.14 \mathrm{pmol} / \mathrm{mg}$ cell protein, $n=5 ; 20 \mu \mathrm{M}$ chloroquine: $9.73 \pm 0.73 \mathrm{pmol} / \mathrm{mg}$ cell protein, $n=5$ ). These results suggest that chloroquine interferes only with the pool of free ionized iron, but does not influence the level of iron complexed into organic molecules.

Figure 5. NOS activity (open bar) and nitrite production (hatched bar) in sEnd.1 cells $(A)$ and PAEC $(B)$ incubated for $6 \mathrm{~h}$ in DME + $10 \% \mathrm{FCS}$, in the presence or absence of $10 \mu \mathrm{g} / \mathrm{ml}$ cycloheximide $(\mathrm{CHX})$ and/or $20 \mu \mathrm{M}$ chloroquine $(\mathrm{CQ})$. After incubation, cells were detached and NOS activity was measured in their lysate, while the extracellular medium was checked for nitrite concentration. Measurements were performed in duplicate, and data are presented as means $\pm \operatorname{SEM}(n=3)$. Versus respective control $(0 \mu \mathrm{MCQ}):{ }^{*} P<$ $0.05, * * P<0.01$. 


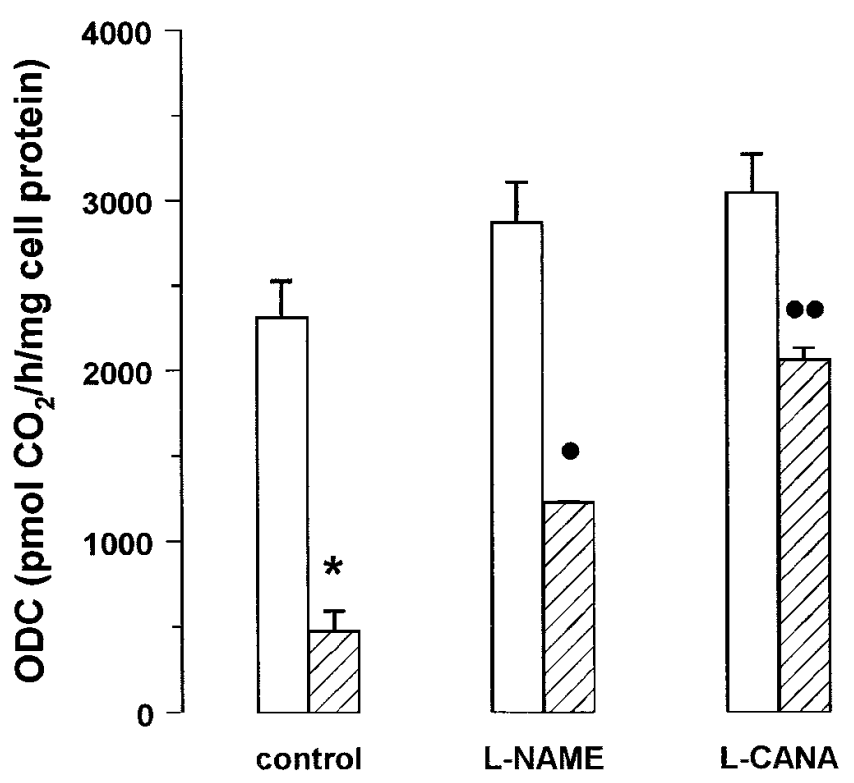

Figure 6. ODC activity in sEnd. 1 cells incubated for $24 \mathrm{~h}$ in DME + $10 \%$ FCS, in the absence (open bar) or presence (hatched bar) of chloroquine $(20 \mu \mathrm{M})$, and in the absence or presence of $\mathrm{N}^{\mathrm{G}}$-nitroL-arginine methyl ester ( $L-N A M E, 1 \mathrm{mM})$ or L-canavanine

$(L-C A N A, 1 \mathrm{mM})$. After incubation, cells were detached and enzyme activity was checked in the lysate (see Methods). Measurements were performed in duplicate, and data are presented as means \pm SEM $(n=3)$. Versus control: ${ }^{*} P<0.0001$; versus chloroquine: (closed circle) $P<0.05$, (two closed circles) $P<0.0001$.

Chloroquine does not influence the level of free cytosolic $\mathrm{Ca}^{++}\left(\left[\mathrm{Ca}^{++}\right] i\right)$. As the $\mathrm{Ca}^{++}$-dependent NOS activity in PAEC was increased after incubation in the presence of chloroquine, we checked the ability of chloroquine to affect $\left[\mathrm{Ca}^{++}\right]$levels, after both long- and short-term stimulation, by using the fluorescent probe Fluo3. This fluorescent indicator was chosen as its fluorescence and absorbance spectra are not altered by chloroquine. $\left[\mathrm{Ca}^{++}\right] \mathrm{i}$ level was $176 \pm 35.8(n=6)$ in control PAEC, and 109.2 $\pm 22.08(n=6, P=\mathrm{NS})$ in PAEC incubated for $24 \mathrm{~h}$ with $20 \mu \mathrm{M}$ chloroquine. The level of $\left[\mathrm{Ca}^{++}\right] \mathrm{i}$ was not modified also when chloroquine was added to control PAEC during fluorometric measurement $(n=6$, data not shown).

Chloroquine does not influence the cytosolic $\mathrm{pH}$ (pHi). As NOS activity has been demonstrated to be influenced by variations of $\mathrm{pHi}$ in rabbit endothelium (41), and chloroquine is a weak base, we explored the possibility that chloroquine activates NOS by inducing an increase of pHi. After a 24-h incubation of PAEC with chloroquine, the pHi $(7.17 \pm 0.03, n=6)$, measured with a fluorescent $\mathrm{pH}$-sensitive probe, was not significantly different from control cells $(7.15 \pm 0.03, n=6)$. Similarly, the addition of $20 \mu \mathrm{M}$ chloroquine to control PAEC cells in $\mathrm{Na}^{+}$-solution did not change the pHi during the following 20 $\min (7.17 \pm 0.04, n=5)$.

The effect of chloroquine is present in human cells too. As chloroquine is a drug used in humans, it is interesting to see whether its effects are evident in human endothelial cells too. When ECV-304 cells (a human endothelial cell line) were incubated for $24 \mathrm{~h}$ with chloroquine, both NOS activity and ni-
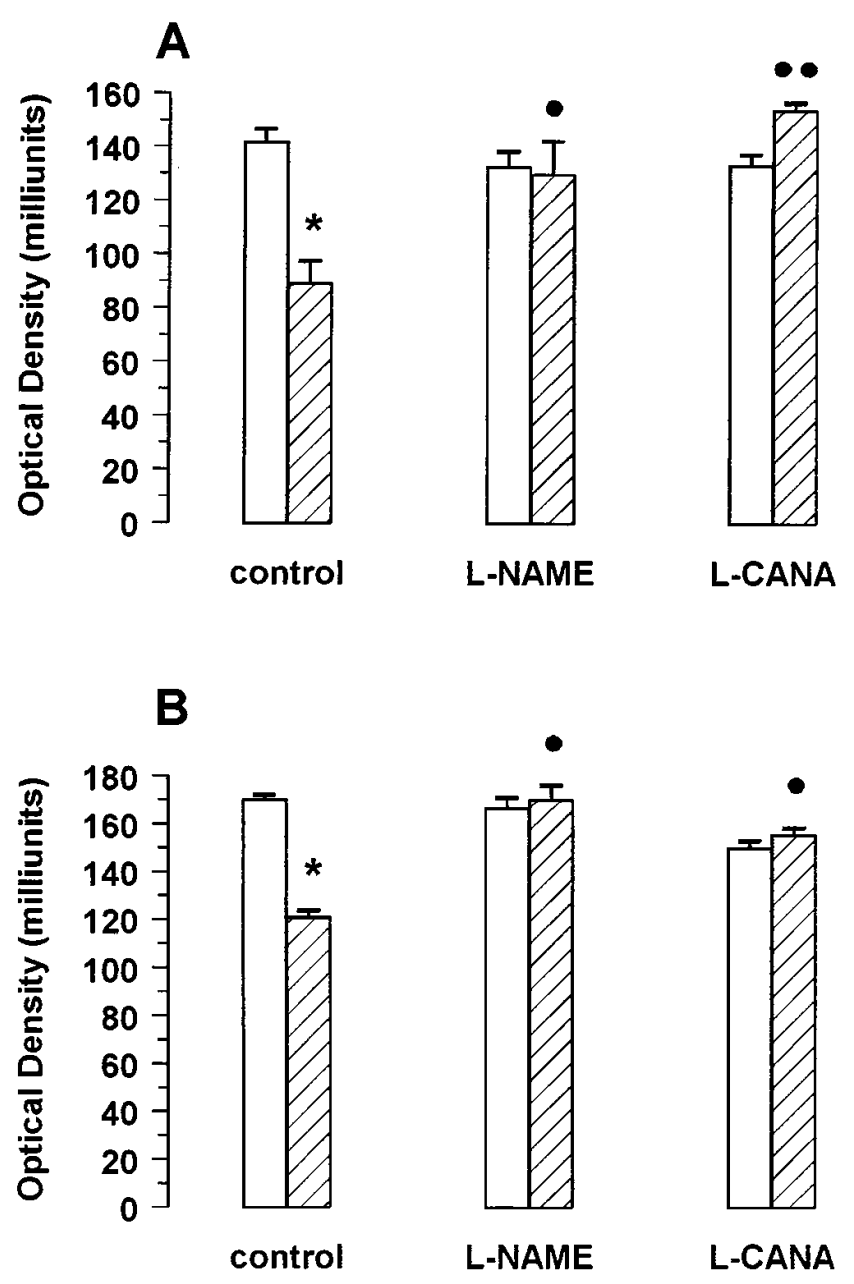

Figure 7. Determination of cell number by crystal violet staining in sEnd.1 cells $(A)$ and PAEC $(B)$ incubated for $24 \mathrm{~h}$ in DME $+10 \%$ FCS, in the absence (open bar) or presence (hatched bar) of chloroquine $(20 \mu \mathrm{M})$, and in the absence or presence of $\mathrm{N}^{\mathrm{G}}$-nitro-L-arginine methyl ester $(L-N A M E, 1 \mathrm{mM})$ or L-canavanine ( $L-C A N A, 1 \mathrm{mM})$. After incubation, cells were stained with crystal violet for cell number determination (expressed as milliunits of optical density; see Methods). Measurements were performed in duplicate, and data are presented as means \pm SEM. $A(n=3)$ : Versus control $* P<0.005$; versus chloroquine (closed circle) $P<0.05$, (two closed circles) $P<0.002$. B $(n=6)$ : Versus control $* P<0.0001$; versus chloroquine (closed circle) $P<0.0001$.

trite production increased significantly by $50 \%$ and $>100 \%$, respectively (Fig. 11); the effect of chloroquine was reverted in both conditions by FeNTA, and nitrite increase was also inhibited by the NOS inhibitor L-canavanine and by the presence of hemoglobin (as packed erythrocytes) in the extracellular medium (Fig. 11).

\section{Discussion}

NO has been found to be effective against a number of pathogenic agents (bacteria, parasites, helminths, viruses, and tumor cells), and plays an important role in acute and chronic inflammation (6). As many other flogistic mediators, it can exert both 

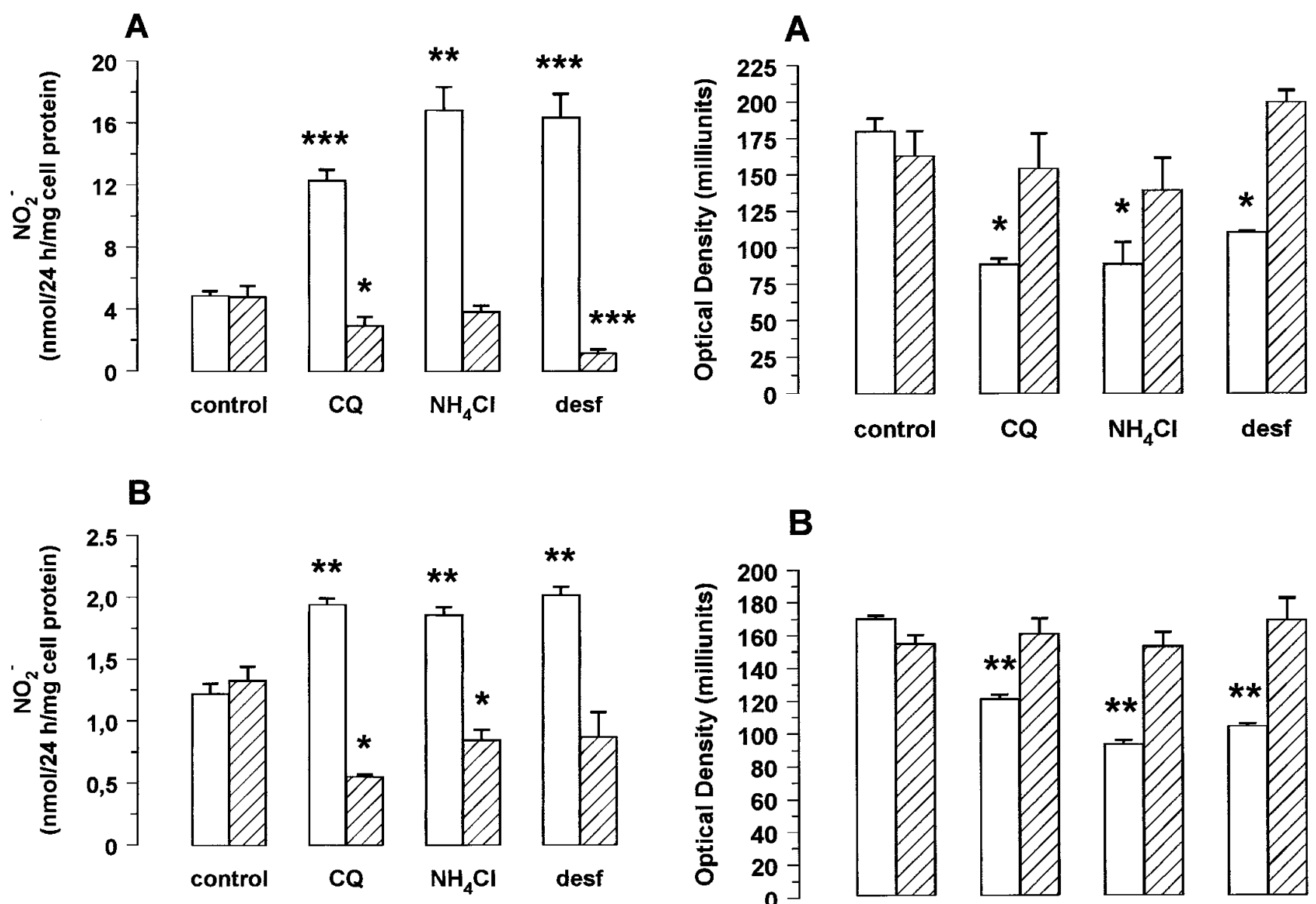

Figure 8. Nitrite production in sEnd.1 cells $(A)$ and PAEC $(B)$ incubated for $24 \mathrm{~h}$ in DME $+10 \%$ FCS, in the absence (open bar) or presence (hatched bar) of $0.3 \mathrm{mM}$ FeNTA and in the absence or presence of $20 \mu \mathrm{M}$ chloroquine $(C Q), 20 \mathrm{mM}$ ammonium chloride $\left(\mathrm{NH}_{4} \mathrm{Cl}\right)$, and $50 \mu \mathrm{M}$ desferrioxamine (desf). After incubation, the extracellular medium was checked for nitrite concentration. Measurements were performed in duplicate, and data are presented as means $\pm \operatorname{SEM}(n=5)$. Versus control: $* P<0.05, * * P<0.005, * * * P<$ 0.001 .

positive and negative effects on the host organism, depending on the site, time, and amount of its production. We investigated the possible involvement of NO in the effects exerted by the antimalarial and antiinflammatory drug, chloroquine. An in vitro incubation of murine and porcine endothelial cells with chloroquine significantly increased NO synthesis, measured as both nitrite accumulation in the cell culture medium and intracellular NOS activity. Nitrite accumulation was prevented by NOS inhibitors or by the NO scavenger hemoglobin, and NOS activity was completely inhibited by NOS inhibitors. Nitrite level and NOS activity give complementary information about NO production, being measured in different experimental conditions. Nitrite accumulation is an index of the actual production of NO by whole cells, whereas the lysate NOS activity indicates the total amount of active enzyme and its maximal activity in the presence of saturating concentrations of substrate. This accounts for the fact that NOS activity and nitrite levels do not exhibit similar increases. The chloroquine effect

was dose dependent, and reached its maximum value at $20 \mu \mathrm{M}$. This concentration is from 2- to 10-fold higher than that measured in serum with the regimens used to treat rheumatoid disease $(23,42)$ or achieved in plasma of malaria patients during intravenous infusion (43) and intramuscular administration (44), but it is very likely to be reached and overcome in endothelial cells lining the vessel wall. Indeed, the drug accumulates thousands-fold in the intracellular acid compartments within few minutes, due to its weak base properties (23), and this leads to a very high gradient of chloroquine through the cell membrane.

Chloroquine in PAEC increased only the $\mathrm{Ca}^{++}$-dependent NOS activity. It is difficult to relate this activity to a specific NOS isoform, as both constitutive and inducible isoenzymes can be activated by $\mathrm{Ca}^{++}$in different tissues (45). In sEnd.1 

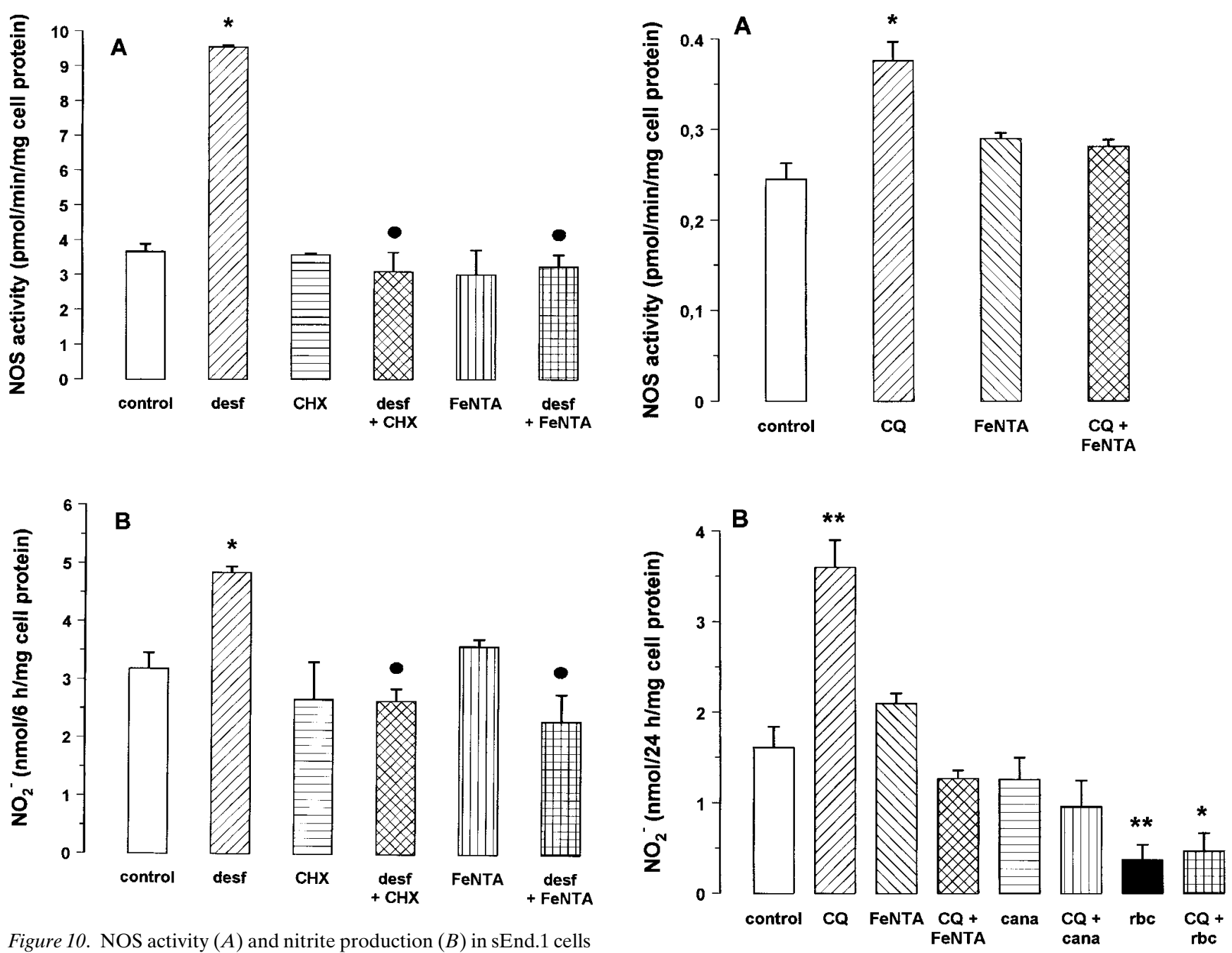

Figure 10. NOS activity $(A)$ and nitrite production $(B)$ in sEnd.1 cells incubated for $6 \mathrm{~h}$ in DME $+10 \%$ FCS, in the presence or absence of $10 \mu \mathrm{g} / \mathrm{ml}$ cycloheximide ( $\mathrm{CHX}$ ), $50 \mu \mathrm{M}$ desferrioxamine (desf), and/ or $0.3 \mathrm{mM}$ ferric nitrilotriacetate (FeNTA). After incubation, cells were detached and NOS activity was measured in their lysate, whereas the extracellular medium was checked for nitrite concentration. Measurements were performed in duplicate, and data are presented as means $\pm \operatorname{SEM}(n=3)$. Versus control: $* P<0.02$; versus desferrioxamine: (closed circle) $P<0.05$.

cells and PAEC, the chloroquine-evoked increase of NOS activity, already detectable after a 6-h incubation, was inhibited by cycloheximide. This suggests that the activation of NO production depended on a de novo synthesis of proteins. As Western blot experiments ruled out that chloroquine induced an increased synthesis of constitutive or inducible NOS, we suppose that NOS activation implicates the expression of a regulatory protein. Furthermore, chloroquine has been shown to inhibit the activities of several enzymes (ATPases, acetylcholinesterase) by inducing reversible changes in the level of membrane phospholipids, cholesterol, and fatty acids (46); eNOS has been found to be regulated by its binding to the cell membranes $(47,48)$, and chloroquine could modulate the enzyme activity by altering the membrane fluidity and NOS compartmentalization.
Figure 11. NOS activity $(A)$ and nitrite production $(B)$ in ECV-304 cells incubated for $24 \mathrm{~h}$ in DME $+10 \%$ FCS, in the presence or absence of $20 \mu \mathrm{M}$ chloroquine $(C Q), 0.3 \mathrm{mM}$ ferric nitrilotriacetate (FeNTA), $1 \mathrm{mM} \mathrm{L-canavanine} \mathrm{(cana),} \mathrm{and/or} 5 \mu \mathrm{l} / \mathrm{ml}$ packed human red blood cells $(r b c)$. After incubation, cells were detached and NOS activity was measured in their lysate, whereas the extracellular medium was checked for nitrite concentration. Measurements were performed in duplicate, and data are presented as means $\pm \operatorname{SEM}(n=3)$. $A$ : versus control $* P<0.02 ; B$ : versus control $* P<0.05$, ** $P<0.01$.

NO may exert cytotoxic effects by several mechanisms: it can block glycolysis, by inhibiting glyceraldehyde 3-phosphate dehydrogenase (49), and cell respiration, via nitrosylation of iron-sulfur clusters of enzymes (cis-aconitase) and electron transporters (complexes I, II, and IV of respiratory chain; 50). Furthermore, NO can elicit nitrosylation of thiol groups (having either activating or, more often, inhibiting effects on protein targets; 51), inhibition of ribonucleotide reductase (leading to inhibition of DNA synthesis; 52), activation of poly(ADP-ribose) synthase (causing depletion of $\mathrm{NAD}^{+}$and ATP; 53), and mutagenesis (54). For these reasons, increased synthesis of NO is often accompanied by inhibition of cell proliferation (2). Also, chloroquine is cytotoxic, but the mechanisms of its action are controversial (23). Intercalation into DNA requires doses of drug much higher (1-2 mM) than those 
effective to inhibit growth of malaria parasites and mammalian cells (23). It has been suggested that chloroquine, consistent with its properties of weak base, accumulates within acid vesicles (coated vesicles, endosomes, lysosomes, Golgi complex, and plasmodium food vacuole), thus interfering with cell functions associated to these membrane-bound compartments (20, 21, 23).

In murine and porcine endothelial cells, chloroquine inhibited cell proliferation via a NO-dependent mechanism, as the number of cultured cells was restored to control levels in the presence of NOS inhibitors. ODC catalyzes the rate-limiting step in the biosynthetic pathway of polyamines, which are essential for cell growth and function (38). ODC inhibition abrogates cells growth, and the activity of this enzyme has shown to be a very sensitive index of the extent of proliferation rate (55). In sEnd.1 cells, chloroquine treatment reduced ODC activity as well as the cell number, and also this inhibition was reverted by NOS inhibitors. Thus, our results suggest that chloroquine inhibits endothelial cells proliferation by stimulating NO synthesis.

Chloroquine is an amphiphilic cationic compound and a potent lysosomotropic agent. To determine if weak base properties are involved in chloroquine-induced stimulation of NO synthesis, we investigated NOS activity in sEnd.1 cells and PAEC incubated with ammonium chloride, a compound widely used, as well as chloroquine, to raise the $\mathrm{pH}$ of acid vesicles in mammalian cells (23). At the concentration generally used to increase vesicle $\mathrm{pH}$, ammonium chloride increased nitrite accumulation and NOS activity up to levels comparable to those achieved with chloroquine. This leads us to suppose that chloroquine activates NOS owing to its ability to increase intravesicular $\mathrm{pH}$.

By disrupting the $\mathrm{pH}$ gradient in the acid vesicles system, chloroquine and ammonium chloride have been reported to alter a number of cell functions, such as receptor-mediated endocytosis, targeting of acid hydrolases, degradation of internalized macromolecules, antigen processing, and cell growth (23). For instance, also intracellular transport and mobilization of iron depend on the normal function of the acid vesicle system: iron enters the cell while still bound to transferrin, via the binding of the iron-transferrin complex to a specific cell surface receptor; iron release from transferrin occurs in acid vesicles, and in many cell types it is inhibited by lysosomotropic agents that elevate vesicular $\mathrm{pH}$, as chloroquine and ammonium chloride $(39,56-60)$. NO production and iron metabolism are two cell functions interrelated in a complex way. Being a hemoprotein, NOS needs iron to be synthesized, and in turn NO causes cells to lose iron, increases expression of transferrin receptor, decreases expression of ferritin, and inhibits heme synthesis (2). In murine macrophages, NOS gene transcription is induced by iron deprivation with desferrioxamine and is inhibited by $\mathrm{Fe}_{3}^{+}$(61). A double regulatory loop between iron and NO has been suggested, in which NO increases "free" cellular iron, and the increase of intracellular concentrations of free iron induces inhibition of NOS transcription (61). Our data suggest that chloroquine and $\mathrm{NH}_{4} \mathrm{Cl}$ activate NOS in endothelial cells by limiting the availability of iron. In fact, their stimulating effects on NO synthesis and inhibiting action on cell proliferation were reverted by iron supplementation with FeNTA, and were mimicked by incubation with desferrioxamine. Chloroquine seems to interfere with the availability of the free iron pool only, as it did not modify the activity of cytosolic aconitase (an enzyme containing an ironsulfur cluster; 40) and the content of total intracellular heme. As the methods used for these measurements rely on the correct redox state of iron in the two molecules, we can conclude that chloroquine does not modify the $\mathrm{Fe}^{++} / \mathrm{Fe}^{+++}$ratio of organic iron.

Chloroquine influenced the $\mathrm{Ca}^{++}$-dependent component of NOS activity, but did not modify per se the level of cytosolic free $\mathrm{Ca}^{++}\left(\left[\mathrm{Ca}^{++}\right] \mathrm{i}\right)$, both immediately after cell stimulation and after a 24-h incubation. This suggests that chloroquine did not increase NOS activity by modifying $\left[\mathrm{Ca}^{++}\right] \mathrm{i}$ levels, in keeping with the long time required for the drug to alter NO synthesis. NOS activity in rabbit endothelium has been attenuated by intracellular acidification produced by a Na${ }^{+} / \mathrm{H}^{+}$exchanger inhibitor (41). As chloroquine is a weak base, we explored the possibility that chloroquine would activate NOS by inducing an increase of $\mathrm{pHi}$. Chloroquine treatment did not significantly affect cytosolic $\mathrm{pH}$ in PAEC, both immediately and after a 24-h incubation, thus indirectly confirming that its main site of action is the acidic compartment of the cell, where it can be concentrated at levels much higher than in cytosolic or extracellular environment (23).

Taken as a whole, our results show that NO synthesis can be stimulated by chloroquine, via an impairment of iron metabolism at the level of the acid cell compartments. This effect is observed in murine, porcine, and human endothelial cells, and is not mediated by an increased synthesis of NOS, but it probably needs the induction of some regulatory protein(s). Thus, our study proposes a further mechanism by which chloroquine may elicit both therapeutic action and side effects. By stimulating the NO synthesis in host cells, chloroquine could potentiate immune response against infective agents. The inhibitory effect exerted by the drug on proliferation of Legionella pneumophila (39) and Histoplasma capsulatum (62) in human mononuclear phagocytes has been attributed to a limited availability of iron to the microorganisms. With the same mechanism, chloroquine could also potentiate NO synthesis and immune reaction of the host cell, thus favoring the inhibition of parasite multiplication. Similarly, chloroquine could potentiate immune response of phagocytes against ingested erythrocytic forms of plasmodia. Our preliminary results suggest that chloroquine induces NO synthesis in human monocytes as well as in endothelial cells. In murine macrophages, chloroquine has been found to inhibit IFN- $\gamma$ and malaria antigen-induced synthesis of nitrite (63), but the effect of chloroquine on basal nitrite production was not investigated. A NOS activation in inflammatory cells could account for a "suicidal" cytotoxic effect, leading to a mitigation of autoimmune or chronic inflammatory diseases sensitive to chloroquine, as rheumatoid arthritis (64), lupus erythematosus (65), active ulcerative colitis (66), and psoriatic arthritis (67). For instance, both chloroquine (21) and NO (68) inhibit T cell proliferation. The efficacy of chloroquine in the therapy of porphyria cutanea tarda (69) could be mediated by NO, which has been reported to inhibit heme synthesis (2). On the other hand, an increased NO production may account for some side effects of chloroquine, mainly observed after treatment with high doses of drug or during parenteral administration: inhibition of platelet aggregation (70), transient hypotension (71), reduced forearm vascular resistance (72), in vivo vasodilation (73), mutagenic effects (74), and neuropathies (75). If so, NOS inhibitors could be associated to high dosage chloroquine 
treatment to prevent the onset of several toxic effects of the drug.

We are now trying to identify the regulatory protein(s) involved in chloroquine-induced NOS activation. Our preliminary results suggest that in PAEC chloroquine increases the expression of ferritin, independently of the intracellular iron contents. Thus, it is conceivable that chloroquine-induced ferritin could act as an iron scavenger, mimicking the effect of desferroxamine on NOS activity. Our further efforts will be addressed to clarify the signaling mechanism by which impairment of acid vesicle system and reduced iron availability activate NOS, to measure the nitrate levels in blood and urine of subjects under chloroquine therapy or prophylaxis, as an index of NO production in vivo, and to extend our study to other cell types.

\section{Acknowledgments}

This study was supported by grants from the Consiglio Nazionale delle Ricerche (94.00240.CT14, 95.02978.CT14, 95.02150.CT04 and 96.03733.CT14), and by grants from Ministero dell'Università e della Ricera Scientifica e Tecnologica (60 and 40\%).

\section{References}

1. Nathan, C. 1992. Nitric oxide as a secretory product of mammalian cells. FASEB (Fed. Am. Soc. Exp. Biol.) J. 6:3051-3064

2. Gross, S.S., and M.S. Wolin. 1995. Nitric oxide: pathophysiological mechanisms. Annu. Rev. Physiol. 57:737-769.

3. Palmer, R.M.J., D.S. Ashton, and S. Moncada. 1988. Vascular endothelial cells synthesize nitric oxide from L-arginine. Nature. 333:664-666.

4. Palmer, R.M.J., and S. Moncada. 1989. A novel citrulline-forming enzyme implicated in the formation of nitric oxide by vascular endothelial cells. Biochem. Biophys. Res. Commun. 158:348-352.

5. Knowles, R.G., and S. Moncada. 1994. Nitric oxide synthases in mammals. Biochem. J. 298:249-258.

6. Schmidt, H.H.H.W., and U. Walter. 1994. NO at work. Cell. 78:919-925.

7. Clark, I.A., K.A. Rockett, and W.B. Cowden. 1991. Proposed link between cytokines, nitric oxide and human cerebral malaria. Parasitol. Today. 7: 205-207.

8. Clark, I.A., K.A. Rockett, and W.B. Cowden. 1992. Possible central role of nitric oxide in conditions clinically similar to cerebral malaria. Lancet. 340: 894-896.

9. Rockett, K.A., M.M. Awburn, B.B. Aggarwal, W.B. Cowden, and I.A. Clark. 1992. In vivo induction of nitrite and nitrate by tumor necrosis factor, lymphotoxin, and interleukin-1: possible roles in malaria. Infect. Immun. 60: 3725-3730.

10. Ghigo, D., R. Todde, H. Ginsburg, C. Costamagna, P. Gautret, F. Bussolino, D. Ulliers, G. Giribaldi, E. Deharo, G. Gabrielli, G. Pescarmona, and A. Bosia. 1995. Erythrocyte stages of Plasmodium falciparum exhibit a high nitric oxide synthase (NOS) activity and release an NOS-inducing soluble factor. $J$. Exp. Med. 182:677-688.

11. Mellouk, S., S.J. Green, C.A. Nacy, and S.L. Hoffman. 1991. IFN- $\gamma$ inhibits development of Plasmodium berghei exoerythrocytic stages in hepatocytes by an L-arginine-dependent effector mechanism. J. Immunol. 146:39713976.

12. Nüssler, A., J.-C. Drapier, L. Renia, S. Pied, F. Miltgen, M. Gentilini, and D. Mazier. 1991. L-arginine-dependent destruction of intrahepatic malaria parasites in response to tumor necrosis factor and/or interleukin 6 stimulation. Eur. J. Immunol. 21:227-230.

13. Rockett, K.A., M.M. Awburn, W.B. Cowden, and I.A. Clark. 1991. Killing of Plasmodium falciparum in vitro by nitric oxide derivatives. Infect. Immun. 59:3280-3283.

14. Nussler, A.K., L. Rènia, V. Pasquetto, F. Miltgen, H. Matile, and D. Mazier. 1993. In vivo induction of the nitric oxide pathway in hepatocytes after injection with irradiated malaria sporozoites, malaria blood parasites or adjuvants. Eur. J. Immunol. 23:882-887.

15. Mellouk, S., S.L. Hoffman, Z.-Z. Liu, P. de la Vega, T.R. Billiar, and A.K. Nussler. 1994. Nitric oxide-mediated antiplasmodial activity in human and murine hepatocytes induced by gamma interferon and the parasite itself: enhancement by endogenous tetrahydrobiopterin. Infect. Immun. 62:4043-4046.

16. Seguin, M.C., F.W. Klotz, I. Schneider, J.P. Weir, M. Goodbary, M. Slayter, J.J. Raney, J.U. Anjagolu, and S.J. Green. 1994. Induction of nitric oxide synthase protects against malaria in mice exposed to irradiated Plasmodium berghei infected mosquitoes: involvement of interferon $\mathrm{g}$ and CD81 T cells. $J$. Exp. Med. 180:353-358.

17. McCall, T., and P. Vallance. 1992. Nitric oxide takes centre-stage with newly defined roles. Trends Pharmacol. Sci. 13:1-6.

18. Taylor-Robinson, A.W., R.S. Phillips, A. Severn, S. Moncada, and F.Y. Liew. 1993. The role of TH1 and TH2 cells in a rodent malaria infection. Science. 260:1931-1934.

19. Wellems, T.E. 1992. How chloroquine works. Nature. 355:108-109.

20. Picot, S., F. Peyron, A. Donadille, J.-P. Vuillez, G. Barbe, and P. Ambroise-Thomas. 1993. Chloroquine-induced inhibition of the production of TNF, but not IL-6, is affected by disruption of iron metabolism. Immunol. 80: $127-133$.

21. Landewè, R.B.M., A.M.M. Miltenburg, M.J.A. Verdonk, C.L. Verweij, F.C. Breedveld, M.R. Daha, and B.A.C. Dijkmans. 1995. Chloroquine inhibits $\mathrm{T}$ cell proliferation by interfering with IL-2 production and responsiveness. Clin. Exp. Immunol. 102:144-151.

22. Slater, A.F.G., and A. Cerami. 1992. Inhibition by chloroquine of a novel haem polymerase enzyme activity in malaria trophozoites. Nature. 355: 167-169.

23. Krogstad, D.J., and P.H. Schlesinger. 1987. Acid-vesicle function, intracellular pathogens, and the action of chloroquine against Plasmodium falciparum. N. Engl. J. Med. 317:542-549.

24. Williams, R.L., S.A. Courtneidge, and E.F. Wagner. 1988. Embryonic lethalities and endothelial tumors in chimeric mice expressing polyoma virus middle T oncogene. Cell. 52:121-131.

25. Gryglewski, R.J., S. Moncada, and R.M.J. Palmer. 1986. Bioassay of prostacyclin and endothelium-derived relaxing factor (EDRF) from porcine aortic endothelial cells. Br. J. Pharmacol. 87:685-694.

26. Bredt, D.S., and S.H. Snyder. 1989. Nitric oxide mediates glutamatelinked enhancement of cGMP levels in the cerebellum. Proc. Natl. Acad. Sci. USA. 86:9030-9033.

27. Knowles, R.G., M. Palacios, R.M.J. Palmer, and S. Moncada. 1989. Formation of a nitric oxide from L-arginine in the central nervous system: a transduction mechanism for stimulation of the soluble guanylate cyclase. Proc. Natl. Acad. Sci. USA. 86:5159-5162.

28. Gross, S.S., E.A. Jaffe, R. Levi, and R.G. Kilbourn. 1991. Cytokine-activated endothelial cells express an isotype of nitric oxide synthase which is tetrahydrobiopterin-dependent, calmodulin-independent and inhibited by arginine analogues with a rank-order of potency characteristic of activated macrophages. Biochem. Biophys. Res. Commun. 178:823-829.

29. Chirgwin, J.M., A.E. Przybyla, R.M. MacDonald, and W.J. Rutter. 1979. Isolation of biologically active ribonucleic acid from sources enriched in ribonuclease. Biochemistry. 18:5294-5299.

30. Maniatis, T., E.F. Fritsch, and J. Sambrook. 1982. Molecular Cloning: A Laboratory Manual. Cold Spring Harbor Laboratory, Cold Spring Harbor, NY. $1.1-18.86$

31. Kao, J.P.Y., A.T. Harootunian, and R.Y. Tsien. 1989. Photochemically generated cytosolic calcium pulses and their detection by Fluo-3. J. Biol. Chem 264:8179-8184.

32. Rabie, A., R.J. Simpson, A. Bomford, D. Cunninghame-Graham, T.J. Peters. 1995. Relationship between duodenal cytosolic aconitase activity and iron status in the mouse. Biochim. Biophys. Acta. 1245:414-420.

33. Schwarzer, E., F. Turrini, and P. Arese. 1994. A luminescence method for the quantitative determination of phagocytosis of erythrocytes, of malariaparasitized erythrocytes and of malarial pigment. Br. J. Haematol. 88:740-745.

34. Thomas, J.A., R.N. Buschbaum, A. Zimniak, and E. Racker. 1979. Intracellular $\mathrm{pH}$ measurements in Ehrlich ascites tumor cells using spectroscopic probes generated in situ. Biochemistry. 18:2210-2218.

35. Bosia, A., D. Ghigo, F. Turrini, E. Nissani, G.P. Pescarmona, and H. Ginsburg. 1993. Kinetic characterization of $\mathrm{Na}^{+} / \mathrm{H}^{+}$antiport of Plasmodium falciparum membrane. J. Cell. Physiol. 154:527-534.

36. Ghigo, D., M.F. Brizzi, G.C. Avanzi, F. Bussolino, G. Garbarino, C. Costamagna, L. Pegoraro, and A. Bosia. 1990. Evidence for a role of the $\mathrm{Na}^{+} /$ $\mathrm{H}^{+}$exchanger in the colony-stimulating-factor-induced ornithine decarboxylase activity and proliferation of the human cell line M-07e.J. Cell. Physiol. 145:147154

37. Kueng, W., E. Silber, and U. Eppenberger. 1989. Quantification of cells cultured on 96-well plates. Anal. Biochem. 182:16-19.

38. Pegg, A.E. 1986. Recent advances in the biochemistry of polyamines in eukaryotes. Biochem. J. 234:249-262.

39. Byrd, T.F., and M.A. Horwitz. 1991. Chloroquine inhibits the intracellular multiplication of Legionella pneumophila by limiting the availability of iron. J. Clin. Invest. 88:351-357.

40. Rouault, T.A., and R.D. Klausner. 1996. Iron-sulfur clusters as biosensors of oxidants and iron. Trends Biochem. Sci. 21:174-177.

41. Ayajiki, K., M. Kindermann, M. Hecker, I. Fleming, and R. Busse. 1996. Intracellular $\mathrm{pH}$ and tyrosine phosphorylation but not calcium determine shear stress-induced nitric oxide production in native endothelial cells. Circ. Res. 78: $750-758$.

42. Augustijns, P., P. Geusens, and N. Verbeke. 1992. Chloroquine levels in blood during chronic treatment of patients with rheumatoid arthritis. Eur. J. Clin. Pharmacol. 42:429-433. 
43. Edwards, G., S. Looareesuwan, A.J. Davies, Y. Wattanagoon, R.E. Phillips, and D.A. Warrell. 1988. Pharmacokinetics of chloroquine in Thais: plasma and red-cell concentrations following an intravenous infusion to healthy subjects and patients with Plasmodium vivax malaria. Br. J. Clin. Pharmacol. 25:477-485.

44. Phillips, R.E., D.A. Warrell, G. Edwards, Y. Galagedera, R.D. Theakston, D.T. Abeysekera, and P. Dissanayaka. 1986. Divided dose intramuscular regimen and single dose subcutaneous regimen for chloroquine: plasma concentrations and toxicity in patients with malaria. Br. Med. J. 293:13-16.

45. Nathan, C., and Q.-W. Xie. 1994. Nitric oxide synthases: roles, tolls, and controls. Cell. 78:915-918.

46. Chandra, S., G. Adhikary, R. Sikdar, and P.C. Sen. 1992. The in vivo inhibition of transport enzyme activities by chloroquine in different organs of rat is reversible. Mol. Cell. Biochem. 118:15-21.

47. Michel, T., G.K. Li, and L. Busconi. 1993. Phosphorylation and subcellular translocation of endothelial nitric oxide synthase. Proc. Natl. Acad. Sci. USA. 90:6252-6256.

48. Michel, T., and O. Feron. 1997. Nitric oxide synthases: which, where, how, and why? J. Clin. Invest. 100:2146-2152.

49. Molina y Vedia, L., B. McDonald, B. Reep, B. Brüne, M. Di Silvio, T.R. Billiar, and E. Lapetina. 1992. Nitric oxide-induced S-nitrosylation of glyceraldehyde-3-phosphate dehydrogenase inhibits enzymatic activity and increases endogenous ADP-ribosylation. J. Biol. Chem. 267:24929-24932.

50. Stuehr, D.J., and C.F. Nathan. 1989. Nitric oxide. A macrophage product responsible for cytostasis and respiratory inhibition in tumor target cells. $J$. Exp. Med. 169:1543-1555.

51. Stamler, J.S., D.I. Simon, J.A. Osborne, M.E. Mullins, O. Jaraki, T. Michel, D.J. Singel, and J. Loscalzo. 1992. S-nitrosylation of proteins with nitric oxide: synthesis and characterization of biologically active compounds. Proc. Natl. Acad. Sci. USA. 89:444-448.

52. Lepoivre, M., F. Fieschi, J. Coves, L. Thelander, and M. Fontecave. 1991. Inactivation of ribonucleotide reductase by nitric oxide. Biochem. Biophys. Res. Commun. 179:442-448.

53. Zhang, J., V.L. Dawson, T.M. Dawson, and S.H. Snyder. 1994. Nitric oxide activation of poly(ADP-ribose) synthetase in neurotoxicity. Science. 263: 687-689.

54. Wink, D.A., K.S. Kasprzak, C.M. Maragos, R.K. Elespuru, M. Misra, T.M. Dunams, T.A. Cebula, W.H. Koch, A.W. Andrews, J.S. Allen, and L.K. Keefer. 1991. DNA deaminating ability and genotoxicity of nitric oxide and its progenitors. Science. 254:1001-1003.

55. Pegg, A.E. 1988. Polyamine metabolism and its importance in neoplastic growth and as a target for chemotherapy. Cancer Res. 48:759-774.

56. Octave, J.-N., Y.-J. Schneider, P. Hoffmann, A. Trouet, and R.R. Crichton. 1979. Transferrin protein and iron uptake by cultured rat fibroblasts. FEBS Lett. 108:127-130.

57. Karin, M., and B. Mintz. 1981. Receptor-mediated endocytosis of transferrin in developmentally totipotent mouse teratocarcinoma stem cells. J. Biol. Chem. 256:3245-3252.

58. Iacopetta, B.J., and E.H. Morgan. 1983. The kinetics of transferrin endocytosis and iron uptake from transferrin in rabbit reticulocytes. J. Biol.
Chem. 258:9108-9115.

59. Armstrong, N.J., and E.H. Morgan. 1983. The effect of lysosomotrophic bases and inhibitors of transglutaminase on iron uptake by immature erythroid cells. Biochim. Biophys. Acta. 762:175-186.

60. Breuer, W., S. Epsztejn, and Z.I. Cabantchik. 1995. Iron acquired from transferrin by $\mathrm{K} 562$ cells is delivered into a cytoplasmic pool of chelatable iron(II). J. Biol. Chem. 270:24209-24215.

61. Weiss, G., G. Werner-Felmayer, E.R. Werner, K. Grünewald, H Wachter, and M.W. Hentze. 1994. Iron regulates nitric oxide synthase activity by controlling nuclear transcription. J. Exp. Med.180:969-976.

62. Newman, S.L., L. Gootee, G. Brunner, and G.S. Deepe, Jr. 1994. Chloroquine induces human macrophage killing of Histoplasma capsulatum by limiting the availability of intracellular iron and is therapeutic in a murine model of histoplasmosis. J. Clin. Invest. 93:1422-1429.

63. Kremsner, P.G., S. Neifer, T. Rasenack, and U. Bienzle. 1993. Interference by antimalarial drugs with the in-vitro production of reactive nitrogen intermediates by murine macrophages. J. Antimicrob. Chemother. 31:385-392.

64. MacKenzie, A.H. 1983. Dose refinements in long-term therapy of rheumatoid arthritis with antimalarials. Am. J. Med. 75(Suppl.):40-45.

65. Rothe, M.J., and F.A. Kerdel. 1992. Treatment of cutaneous lupus erythematosus. Lupus. 1:351-356.

66. Goenka, M.K., R. Kochhar, B. Tandia, and S.K. Mehta. 1996. Chloroquine for mild to moderately active ulcerative colitis: comparison with sulfasalazine. Am. J. Gastroenterol. 91:917-921.

67. Sayers, M.E., and D.J. Mazanec. 1992. Use of antimalarial drugs for the treatment of psoriatic arthritis. Am. J. Med. 93:474-475.

68. Lejeùne, P., P. Lagadec, N. Onier, D. Pinard, H. Ohshima, and J.-F. Jeannin. 1994. Nitric oxide involvement in tumor-induced immunosuppression. J. Immunol. 152:5077-5083.

69. Valls, V., J. Ena, and R. Enriquez-De-Salamanca. 1994. Low-dose oral chloroquine in patients with porphyria cutanea tarda and low-moderate iron overload. J. Dermatol. Sci. 7:169-175.

70. Jancinova, V., R. Nosal, and M. Petrikova. 1994. On the inhibitory effect of chloroquine on blood platelet aggregation. Thromb. Res. 74:495-504.

71. White, N.J., K.D. Miller, F.C. Churchill, C. Berry, J. Brown, S.B. Williams, and B.M. Greenwood. 1988. Chloroquine treatment of severe malaria in children. Pharmacokinetics, toxicity, and new dosage recommendations. $N$. Engl. J. Med. 319:1493-1500.

72. Anigbogu, C.N., S.A. Adigun, I. Inyang, and B.J. Adegunloye. 1993 Chloroquine reduces blood pressure and forearm vascular resistance and increases forearm blood flow in healthy young adults. Clin. Physiol. 13:209-216.

73. Abiose, A.K., M. Grossmann, O. Tangphao, B.B. Hoffman, and T.F. Blaschke. 1997. Chloroquine-induced venodilation in human hand veins. Clin. Pharmacol. Ther. 61:677-683.

74. Espinosa-Aguirre, J.J., J. Ramirez Santos, and C. Cortinas de Nava 1989. Influence of the Uvr repair system on the mutagenicity of antiparasitic drugs. Mutation Res. 222:161-166.

75. Tegner, R., F.M. Tome, P. Godeau, F. Lhermitte, and M. Fardeau. 1988. Morphological study of peripheral nerve changes induced by chloroquine treatment. Acta Neuropathol. 75:253-260. 